\title{
POTENSI PENYELEWENGAN ALOKASI DANA DESA DI KAJI MENURUT PERATURAN MENTERI DALAM NEGERI NOMOR 37 TAHUN 2007 TENTANG PENGELOLAAN KEUANGAN DESA
}

\author{
Yuyun Yulianah \\ Dosen Fakultas Hukum Universitas Suryakancana
}

\begin{abstract}
ABSTRAK
Banyaknya bantuan pemerintah yang dialokasikan untuk pembangunan desa merupakan salah satu bentuk perhatian pemerintah daerah kepada desa namun dalam hal ini Potensi penyelewengan keuangan Desa, jelas sangat besar. Hal ini tidak terlepas dari kelemahan pengawasan dari Aparat pemerintah kabupaten terhadap alur proses mengalirnya dana, Di samping itu yang tidak kalah pentinggnya adalah Sumber Daya manusia dari Aparat Pemerintahan Desa itu sendiri yang pada umumnya lemah. Jumlah Alokasi Dana Desa (ADD) yang diterima oleh Kepala Desa sangatlah kecil dan tidak sebanding dengan tanggungjawab kepala Desa yang diharapkan dapat mengorganisir pembangunan desa. Apalagi budaya pemotongan ADD oleh oknum birokrasi sehingga yang diterima oleh pemerintah desa menjadi kecil.
\end{abstract}

Kata Kunci : Otonomi Daerah, Alokasi Dana Desa

\begin{abstract}
A lot of government aid which is allocated for village development is kind of government attention to rural areas. However, in this case the potency of Village financial fraud is more likely to happen. It is not apart from the lack of the supervision from district government officials on the funds flow process. In addition, which is also important is the human resources of government officials in the village itself were generally weak. The amount of the Village Fund Allocation (ADD) received by the Head of Village is quite small and is not comparable with the responsibility of the head of the village which is expected to organize village development. Even worse, the ADD fraud culture by unscrupulous bureaucracy has caused the fund received by the village was pretty small.
\end{abstract}

Keywords: Regional Autonomy, Village Fund Allocation. 


\section{PENDAHULUAN.}

Kebijakan Desentralisasi yang efektif dilaksanakan sejak tahun 2001 pada gilirannya akan meningkatkan kesempatan bagi Pemerintahan Daerah untuk memberikan alternatif pemecahan secara inovatif dalam menghadapi tantangan yang dihadapi. Pemerintah Daerah dituntut untuk memberikan perhatian yang lebih besar terhadap kualitas penyelenggaraan pelayanan publik serta meningkatkan kemandirian dalam melaksanakan pembangunan. ${ }^{1}$

Penyelenggaraan pemerintahan sesuai dengan ketentuan Pasal 18 UUD 1945 tidak bersifat sentralistik, melainkan dengan pemerataan kewenangan secara vertikal yang melahirkan pemerintahan daerah. Beranjak dari ketentuan Pasal 18 UUD 1945 nampak bahwa Negara Indonesia sebagai Negara Kesatuan menganut asas desentralisasi dalam penyelenggaraan pemerintahan dengan memberi kesempatan dan kewenangan kepada daerah untuk menyelenggarakan otonomi daerah. Dalam Negara Kesatuan pembagian kewenangan secara vertikal merupakan pembagian kewenangan antara Pemerintah Pusat dan Pemerintah Daerah yang dilakukan dengan cara atribusi atau delegasi. ${ }^{2}$

Desentralisasi dapat diartikan penyerahan atau pengakuan hak atas kewenangan untuk mengurus rumah tangga daerah sendiri, dalam hal ini daerah diberi kesempatan untuk melakukan suatu kebijakan sendiri. Pengakuan tersebut merupakan suatu bentuk partisipasi rakyat dalam pengambilan keputusan yang merupakan ciri dari negara demokrasi. Desentralisasi adalah pendelegasian wewenang dalam membuat keputusan dan kebijakan pada level bawah pada suatu organisasi. ${ }^{3}$

1 Hamzah Halim dan Kemal Redindo Syahrul Putera, Cara Praktis Menyusun \& Merancang Peraturan Daerah; Suatu Kajian Teoritis \& Praktis Disertai Manual; Konsepsi Teoritis Menuju Artikulasi Empiris, Kencana Prenada Media Group, Jakarta, 2010. hlm. 82.

2 Maurice Duverger, dalam Kuntjoro Purbopranoto, Sistem Pemerintahan Demokrasi, cet 3. PT.Eresco, Bandung, 1978. HIm. 92.

3 Hamzah Halim dan Kemal Redindo, Op Cit, hlm 90. 
Ten Berge mengartikan desentralisasi sebagai suatu penyerahan atau pengakuan hak (mengenai keadaan yang telah dinyatakan) atas kewenangan untuk pengaturan dan pemerintahan dan badan-badan hukum publik yang rendahan atau organ-organ dalam hal mana ini diberi kesempatan untuk melakukan suatu kebijaksanaan sendiri. Istilah otonomi lebih cenderung pada Political Aspect (aspek politik-kekuasaan negara), sedangkan desentralisasi lebih cenderung pada administrative aspect (aspek administrasi negara). Namun jika dilihat dari konteks pembagian kewenangan dalam praktiknya, kedua istilah tersebut mempunyai keterkaitan yang erat dan tidak dapat dipisahkan. Artinya jika berbicara mengenai otonomi daerah tentu akan menyangkut pertanyaan seberapa wewenang yang akan diberikan kepada pemerintah daerah untuk menyelenggarakan urusan pemerintahan, demikian sebaliknya. ${ }^{4}$

Desa adalah bentuk pemerintahan terkecil yang ada di negeri ini. Luas wilayah desa biasanya tidak terlalu luas dan dihuni oleh sejumlah keluarga. Mayoritas penduduknya bekerja di bidang agraris dan tingkat pendidikannya cenderung rendah. Karena jumlah penduduknya tidak begitu banyak, maka biasanya hubungan kekerabatan antar masyarakatnya terjalin kuat. Para masyarakatnya juga masih percaya dan memegang teguh adat dan tradisi yang ditinggalkan para leluhur mereka. Sebagai bagian terkecil dari sistem pemerintahan di Indonesia, Desa memegang peranan penting terutama berkaitan dengan pembangunan-pembangunan yang langsung menyentuh kepada masyarakat. Banyak program yang dikeluarkan oleh Pemerintah untuk terciptanya tatanan kehidupan desa yang lebih baik dan lebih mensejahterakan rakyatnya.

Disatu sisi sebagai satuan pemerintahan terkecil, desa memerlukan aparatur penunjang pemerintahan yang handal, yang mampu menggali potensi-potensi keuangan desa serta mampu memberikan pengayoman yang optimal kepada masyarakat. Akan tetapi di sisi lain, sumber daya manusia aparatur desa itu sendiri

$4 \quad$ Ibid, hlm 93. 
umumnya masih lemah dan terbatas. Sementara berbagai bantuan langsung diberikan oleh pemerintah kepada desa dalam berbagai bentuk dan variasinya, baik bantuan berupa dana tunai langsung, sarana atau alat maupun bentuk lain (bibit, benih, dan sebagainya).

Bantuan-bantuan tersebut diberikan secara langsung melalui desa untuk disalurkan langsung kepada masyarakat agar masyarakat membudidayakannya. Akan tetapi dalam kenyataannya bantuan-bantuan tersebut ada yang tersalurkan kepada masyarakat ada pula yang tidak sampai, melainkan dimanfaatkan oleh kelompokkelompok tertentu. Banyaknya bantuan pemerintah yang dialokasikan untuk pembangunan desa merupakan salah satu bentuk perhatian pemerintah daerah kepada desa. Sumber-sumber Keuangan Desa Menurut Peraturan Pemerintah (PP) Nomor 72 Tahun 2005 dijelaskan bahwa pendapatan Desa terdiri dari : 1) Pendapatan Asli Desa (PAD) terdiri dari : Hasil kekayaan desa; hasil swadaya dan partisipasi; serta gotong royong. 2) Pembagian Pajak atau Restibusi Kabupaten 3) Dana Perimbangan Pusat dan Daerah Kabupaten atau Alokasi Dana Desa (ADD), 4) Bantuan Keuangan Dari Pemerintah Propinsi dan Kabupaten, dan 5) Hibah dan sumbangan dari pihak ketiga yang tidak mengikat.

PP No 72 Tahun 2005 tersebut dijelaskan pula bahwa minimalnya 10\% dari sumber pendapatan daerah yang diterima Kabupaten yang diterima dari dana perimbangan propinsi dan daerah, selanjutnya di bagi secara proporsional yakni $30 \%$ untuk biaya operasional dan $70 \%$ untuk kegiatan pemberdayaan masyarakat. Sementara itu dalam Peraturan Menteri Dalam Negeri (PERMENDAGRI) Nomor 37 Tahun 2007 Tentang Pedoman Pengelolaan Keuangan Desa disebutkan bahwa, Pendapatan Desa terdiri dari: a) Pendapatan Asli Desa (PADesa); b) Bagi Hasil Pajak Kabupaten/Kota; c) Bagian dari Retribusi Kabupaten/Kota; d) Alokasi Dana Desa (ADD); e) Bantuan Keuangan dari Pemerintah, Pemerintah Provinsi, Pemerintah Kabupaten/Kota dan Desa lainnya; f) Hibah; dan g) Sumbangan Pihak Ketiga.

Jumlah Alokasi Dana Desa (ADD) yang diterima oleh Kepala Desa sangatlah kecil dan tidak sebanding dengan tanggungjawab Kepala Desa yang diharapkan dapat 
mengorganisir pembangunan desa. Apalagi budaya pemotongan ADD oleh oknum birokrasi sehingga yang diterima oleh Pemerintah Desa menjadi kecil. Sedangkan Pendapatan Asli Desa (PAD) hanya mengandalkan satu-satunya kekayaan desa adalah tanah Bengkok yang dimiliki oleh pemerintah desa. Hal tersebut memaksa pemerintah desa membuat proposal proyek Infrastruktur sebanyak mungkin ke Pemerintah Kabupaten.

Sedikitnya Alokasi Dana Desa dari pemerintah Kabupaten, hal ini diperparah dengan banyaknya oknum-oknum, baik dari Desa maupun kecamatan yang memanfaatkan ADD tanpa hak dan kewenangan. Potensi penyelewengan keuangan Desa, jelas sangat besar, hal ini tidak terlepas dari kelemahan pengawasan dari aparat pemerintah kabupaten terhadap alur proses mengalirnya dana. Disamping itu yang tidak kalah pentinggnya adalah Sumber Daya manusia dari aparat pemerintahan desa itu sendiri yang pada umumnya lemah.

\section{PEMBAHASAN.}

\section{A. Kebijakan Penerapan Alokasi Dana Desa.}

Pada dasarnya pembangunan di Negara Indonesia ditopang oleh pembangunan di tingkat nasional dan provinsi, demikian juga maju mundurnya pembangunan di propinsi tidak terlepas dari pembangunan di Kabupaten-kabupaten yang berada di bawahnya. Dan sudah barang tentu maju mundurnya Kabupaten tergantung pada pembangunan di kelurahan dan desa-desa di bawah pemerintahannya. Demikian pula dengan laju pertumbuhan perekonomian disuatu daerah baik Kabupaten maupun propinsi tidak terlepas dari kemajuan pembangunan ekonomi di desa-desa.

Undang-Undang Nomor 23 Tahun 2014 Tentang Pemerintahan Daerah mengatur secara khusus mengenai pendpatan daerah, yang di atur dalam Pasal 1 ayat 35 menyatakan bahwa "Pendapatan Daerah adalah semua hak Daerah yang diakui sebagai penambah nilai kekayaan bersih dalam periode tahun anggaran yang bersangkutan", dan pada Pasal 380 dalam penjelasan ayat 2, yaitu : 
"Khusus untuk pengawasan yang terkait keuangan Daerah meliputi kegiatan audit, reviu, evaluasi, pemantauan, dan bimbingan teknis dalam pengelolaan APBD kabupaten/kota yaitu sejak tahap perencanaan, pelaksanaan, pemantuan dan evaluasi atas pelaksanaan APBD (termasuk penyerapan APBD), sampai dengan pertanggungjawaban pelaksanaan APBD kabupaten/kota yang dilakukan inspektorat kabupaten/kota dapat bekerja sama dengan Inspektorat Jenderal Kementerian dan/atau lembaga pemerintah nonkementerian yang menyelenggarakan urusan pemerintahan bidang pengawasan".

Adapun dana desa yang di atur dalam Pasal 285 ayat 2 dalam penjelasan angka 4 yaitu :

"Yang dimaksud dengan "dana Desa" adalah dana yang bersumber dari APBN yang diperuntukan bagi Desa yang ditransfer melalui APBD kabupaten/kota dan digunakan untuk membiayai penyelenggaraan pemerintahan Desa yang mencakup pelayanan, pembangunan, dan pemberdayaan masyarakat".

Sumber pendapatan desa antara lain, Pendapatan asli desa, bagi hasil pajak daerah dan retribusi daerah kabupaten/kota, bagian dari dana perimbangan keuangan pusat dan daerah yang diterima oleh kabupaten/kota, bantuan dari pemerintah, pemerintah propinsi, dan pemerintah kabupaten/kota, hibah dan sumbangan dari pihak ketiga. Kenyataan menunjukkan bahwa sumber-sumber keuangan desa sebagaimana dimaksud di atas belum sepenuhnya dikelola secara optimal, terutama sumber pendapatan desa yang berasal dari pendapatan asli desa. Hal ini tidak terlepas dari berbagai faktor penghambat, yang salah satunya masih terbatas atau lemahnya Sumber Daya Manusia (SDM) aparatur pemerintahan desa itu sendiri. Dengan demikian hampir dapat dipastikan, banyak desa yang hanya bergantung pada bantuan dari pemerintah pusat, provinsi maupun Kabupaten. Kenyataan ini masih ditambah dengan kurangnya peraturan perundang-undangan maupun peraturan lainnya yang secara spesifik mengatur tentang pengelolaan keuangan desa. Padahal tidak sedikit dana yang disalurkan pemerintah pusat, propinsi maupun Kabupaten untuk Desa. Alhasil tujuan penyelenggaraan otonomi daerah yakni memajukan perekonomian di daerah, menciptakan efisiensi dan efektivitas pengelolaan sumber kekayaan daerah, 
sulit untuk dicapai. ${ }^{7}$ Tidak jarang Keuangan dari pemerintah yang tidak dikelola dengan baik hanya menguntungkan sekelompok orang desa saja. Sudah menjadi rahasia umum bahwa ketersediaan sumber daya manusia yang kompeten dan professional. Disamping itu sumber pembiayaan yang masih kurang memadai baik yang berasal dari desa itu sendiri maupun dari luar. ${ }^{8}$

Desa mempunyai hak untuk memperoleh bagi hasil pajak daerah dan retribusi daerah dan bagian dari dana perimbangan keuangan pusat dan daerah yang diterima oleh Kabupaten/Kota. Bagian perolehan desa dari Kabupaten disebut Alokasi Dana Desa (ADD) yang disalurkan melalui kas desa. Pemberian ADD merupakan wujud pemenuhan hak desa untuk menyelenggarakan otonominya agar tumbuh dan berkembang berdasarkan keanekaragaman, partisipasi, otonomi asli, demokratisasi dan pemberdayaan masyarakat itu sendiri. ${ }^{9}$

Melalui Alokasi Dana Desa, desa ataupun kelurahan berpeluang untuk mengelola pembangunan, pemerintahan dan sosial kemasyarakatan desa secara otonom. Alokasi Dana Desa adalah dana yang diberikan kepada desa yang berasal dari dana perimbangan keuangan pemerintah pusat dan daerah yang diterima oleh Kabupaten/Kota. Pemberian Alokasi Dana Desa merupakan wujud dari pemenuhan hak desa untuk menyelenggarakan otonominya agar tumbuh dan berkembang mengikuti pertumbuhan dari desa itu sendiri berdasarkan keanekaragaman, partisipasi, otonomi asli, demokratisasi, pemberdayaan masyarakat dan meningkatkan peran Pemerintah Desa dalam memberikan pelayanan dan meningkatkan

7 Mardiasmo, Otonomi dan Manajemen Keuangan Daerah, Penerbit Andi, Yogyakarta, 2004. hlm. 59.

8 Maryunani, Keuangan dan Ekonomi Desa, Makalah, Fakultas Ekonomi Universitas Brawijaya, Malang, 2006.

9 Sukesi, Efektivitas Program Alokasi Dana Desa (ADD) Terhadap Perekonomian Desa Di Kabupaten Pacitan, Jurnal Ilmiah, Universitas Dokter Sutomo, Surabaya, Vol. 1 Desember Tahun 2007. hlm. 43. 
kesejahteraan masyarakat serta memacu percepatan pembangunan dan pertumbuhan wilayah-wilayah strategis. ${ }^{10}$

Alokasi Dana Desa sangat penting guna pembiayaan pengembangan wilayah tertinggal dalam suatu sistem wilayah pengembangan. Pelaksanaan Alokasi Dana Desa ini ditujukan untuk program-program fisik dan non fisik yang berhubungan dengan indikator Perkembangan Desa, meliputi tingkat pendidikan, tingkat pendapatan masyarakat, dan tingkat kesehatan. ${ }^{11}$ Penggunaan Anggaran Alokasi Dana Desa adalah sebesar 30\% (tiga puluh persen) untuk belanja aparatur dan operasional Pemerintah Desa, sebesar 70\% (tujuh puluh persen) untuk biaya pemberdayaan masyarakat. Bagi Belanja Pemberdayaan Masyarakat digunakan untuk Biaya perbaikan sarana publik dalam skala kecil, penyertaan modal usaha masyarakat melalui BUMDesa, biaya untuk pengadaan ketahanan pangan, perbaikan lingkungan dan pemukiman, teknologi tepat guna, perbaikan kesehatan dan pendidikan, pengembangan sosial budaya, dan sebagainya yang dianggap penting.

Pada pelaksanaannya, permasalahan yang muncul adalah kurang tepatnya pencapaian sasaran program. Artinya program-program yang semula dianggarkan untuk dibiayai seringkali digantikan oleh program lain yang ternyata memiliki kepentingan yang lebih besar untuk diprioritaskan. Hal ini diperparah dengan adanya beberapa jenis kegiatan yang dibiayai oleh ADD yang digunakan untuk kepentingan pribadi atau kelompok. Peraturan Pemerintah Nomor 72 Tahun 2005 Tentang Desa mengatur bahwa Penyelenggaraan Urusan Pemerintah Desa didanai dari Anggaran Pendapatan dan Belanja Desa dan Bantuan Pemerintah Desa. Aturan tersebut diperkuat dengan SK Menteri Dalam Negeri Nomor: 140/640SJ tanggal 22 Maret 2005 tentang Pedoman Alokasi Dana Desa dari pemerintah Kabupaten kepada Pemerintah Desa, serta Peraturan Menteri Dalam Negeri Nomor 37 Tahun 2007 Tentang Pedoman Pengelolaan Keuangan Desa.

10 Bayu Sukmawan Budiyono, Pelaksanaan Kebijakan Alokasi Dana Desa Berdasarkan Permendagri No. 37 Tahun 2007 Tentang Pedoman Pengelolaan Keuangan Desa, Jurnal ilmiah, Fakultas Hukum Universitas Brawijaya, Malang, 2013. hlm. 4.

11 Ibid. 
Melalui Alokasi Dana Desa, Desa ataupun Kelurahan berpeluang untuk mengelola pembangunan, pemerintahan dan sosial kemasyarakatan desa secara otonom. Alokasi Dana Desa adalah dana yang diberikan kepada desa yang berasal dari dana perimbangan keuangan pemerintah pusat dan daerah yang diterima oleh Kabupaten/Kota. Pemberian Alokasi Dana Desa merupakan wujud dari pemenuhan hak desa untuk menyelenggarakan otonominya agar tumbuh dan berkembang mengikuti pertumbuhan dari desa itu sendiri berdasarkan keanekaragaman, partisipasi, otonomi asli, demokratisasi, pemberdayaan masyarakat dan meningkatkan peran Pemerintah Desa dalam memberikan pelayanan dan meningkatkan kesejahteraan masyarakat serta memacu percepatan pembangunan dan pertumbuhan wilayah-wilayah strategis.

Alokasi Dana Desa sangat penting guna pembiayaan pengembangan wilayah tertinggal dalam suatu sistem wilayah pengembangan. Pelaksanaan Alokasi Dana Desa ini ditujukan untuk program-program fisik dan non fisik yang berhubungan dengan indikator Perkembangan Desa, meliputi tingkat pendidikan, tingkat pendapatan masyarakat, dan tingkat kesehatan. Alokasi Dana Desa dikelola oleh Pemerintah Desa dengan ketentuan penggunaan sesuai PP No. 72 Tahun 2005 Tentang Desa. Sejumlah 30\% (tiga puluh persen) Alokasi Dana Desa digunakan untuk Biaya Operasional Pemerintah Desa, sedangkan 70\% (tujuh puluh pesen) Alokasi dana Desa digunakan untuk membiayai Kegiatan Pemberdayaan Masyarakat Desa.

Bantuan Langsung Alokasi Dana Desa (ADD) dimaksudkan sebagai bantuan stimulant atau dana perangsang untuk mendorong dalam membiayai program pemerintah desa yang ditunjang dengan partisipasi swadaya gotong royong masyarakat dalam melaksanakan kegiatan pemerintahan dan pemberdayaan. Pengelolaan Bantuan Langsung Alokasi Dana Desa (ADD) harus berpedoman pada prinsip-prinsip pengelolaan, yang meliputi:

a) Penyaluran dana harus langsung ditujukan kepada pengelola/penerima, b) Rencana kegiatan dilakukan dengan tertib dan harus dapat diketahui oleh 
seluruh lapisan masyarakat dengan mudah dan terbuka, c) Seluruh kegiatan harus dapat dipertanggungjawabkan baik secara teknis maupun administrasi, d) Pelaksanaan ADD harus sudah selesai pada akhir bulan Desember tahun anggaran yang sedang berjalan, e) Apabila sampai akhir bulan Desember belum dapat selesai atau belum mencapai $100 \%$ (seratus persen) dan terdapat sisa dana, maka sisa dana tersebut dikembalikanke Kas Daerah, dan f) Hasil kegiatan/proyek yang dibangun menjadi milik desa dan dapat dilestarikan serta dikembangkan oleh pemerintah desa dan masyarakat.

Pelaksanaan kebijakan alokasi dana desa mencakup berbagai proses yang meliputi penyusunan rencana kegiatan dengan menyusun DURK masing-masing desa yang disampaikan kepada Pemerintah Kabupaten. Setelah memperoleh persetujuan maka secara fisik berbagai usulan kegiatan tersebut diimplementasikan secara bertahap. Sebagaimana peraturan-peraturan lainnya, dalam proses penyusunan maupun implementasinya tidak akan terlepas dari ketentuan-ketentuan lain yang lebih tinggi tingkatannya. Oleh karena itu tidak sedikit Peraturan Daerah disusun hanya memindahkan dari peraturan yang lebih tinggi ke dalam Peraturan Daerah tersebut. Hal ini bertentangan dengan asas-asas dalam penyusunan suatu peraturan yakni Asas kejelasan tujuan, asas kelembagaan/organ pembentuk, asas kesesuaian antara jenis dan materi muatan, asas dapat dilaksanakan, asas kedayagunaan dan kehasilgunaan, asas kejelasan rumusan dan asas keterbukaan. ${ }^{12}$

Secara substantif atau material, suatu peraturan daerah harus dijiwai oleh asasasas sebagai berikut yaitu, asas pengayoman, asas kemanusiaan, asas kebangsaan, asas kekeluargaan, asas kenusantaraan, asas bhineka tunggal ika, asas keadilan, asas kesamaan, asas ketertiban dan kepastian hukum; dan asas keseimbangan, keserasian, dan keselarasan. ${ }^{13}$

Dana Desa sebagaimana dimaksud di atas, dialokasikan terhadap kegiatankegiatan pembangunan di Desa sebagai berikut, a) Menanggulangi kemiskinan dan mengurangi kemiskinan; b) Meningkatkan perencanaan dan penganggaran

12 Menjembatani Penelitian dan Kebijakan, dikutip dari http://www.smeru.or.id, 7 September 2015. 13 Ibid. 
pembangunan desa dan pemberdayaan masyarakat; c) Meningkatkan pembangunan infrastruktur perdesaan; d) Meningkatkan pengamalan nilai-nilai keagamaan, sosial budaya dalam rangka mewujudkan peningkatkan sosial; e) Meningkatkan ketentraman dan ketertiban masyarakat; f) Meningkatkan pelayanan kepada masyarakat desa dalam rangka pengembangan kegiatan sosial dan ekonomi masyarakat; g) Mendorong peningkatkan keswadayaan dan gotong royong masyarakat; dan h) Meningkatkan pendapatan desa dan masyarakat desa melalui Badan Usaha Milik Desa.

\section{B. Potensi Penyelewengan Terhadap Alokasi Dana Desa.}

Keberhasilan implementasi sebuah kebijakan salah satu faktor yang menentukannya adalah sosialisasi yang merupakan proses pengkomunikasian kegiatan. Terdapat 3 (tiga) hal yang perlu diperhatikan, yaitu transmisi, clarity, consistency. Dari hasil penelitian dalam hubungan sosialisasi dan pelaksanaan ADD, terdapat beberapa faktor penentu yaitu :

1) Sosialisasi telah dilakukan oleh Tim Kabupaten sementara pengawasan didelegasikan pada pelaksana program melalui pelaksanaan pertanggungjawaban kerja, 2) Pencapaian informasi dari pembuat kebijakan ke pelaksana kebijakan maupun sebaliknya berjalan lancar sehingga memudahkan sistem control, dan 3) Terdapat konsistensi dalam pencapaian pesan/perintah kebijakan artinya tidak terdapat perintah yang bertentangan.

Alokasi Dana Desa (ADD) merupakan dana dari pemerintah daerah yang langsung masuk pada rekening desa, dimana dalam penggunaannya merupakan kewenangan penuh dari Kepala Desa. Dengan demikian, akan sangat rentan terhadap penyelewengan karena dalam perencanaan kegiatan pun merupakan kewenangan Kepala Desa, sementara masyarakat yang dalam hal ini diwakili oleh Badan Permusyawaratan Desa (BPD) hanya sebatas memberikan masukan kepada Kepala Desa berdasarkan aspirasi dari masyarakat.

Modus penyelewengan yang umumnya dilakukan oleh aparat pemerintah desa, terhadap Alokasi Dana Desa (ADD) yang umumnya terjadi antara lain: 1) 
Menggunakan ADD untuk kepentingan pribadi; 2) Mengalihkan dana untuk program lain; 3) Memasukan kegiatan baru yang sebelumnya tidak direncanakan; 4) Memanipulasi laporan penggunaan ADD; 5) Dana ADD digunakan untuk menutupi setoran PBB; 5) Pembelian barang inventaris desa; 6) Pengalokasian ADD yang tidak sesuai dengan ketentuan; 7) Kepala Desa tidak mengalokasikan dana untuk kegiatan kemasyarakatan yang seharusnya di biayai oleh ADD.

Dikaji dari Undang-Undang Nomor 31 Tahun 1999 Tentang Pemberantasan Tindak Pidana Korupsi, Penyelewengan ADD merupakan salah satu bentuk tindak pidana korupsi. Hal ini didasarkan pada rumusan dari tindak pidana korupsi sebagaimana dirumuskan dalam undang-undang tersebut, dari bunyi ketentuan tersebut jelas bahwa tindakan Kepala Desa yang menyalahgunakan ADD untuk kepentingan pribadi merupakan salah satu bentuk tindak pidana korupsi. Untuk lebih jelasnya dapat dikaji dari ciri-ciri khas perbuatan korupsi, yaitu :

a) Melibatkan lebih dari satu orang, b) Korupsi tidak hanya berlaku di kalangan pegawai negeri atau anggota birokrasi negara, korupsi juga terjadi di organisasi usaha swasta, c) Korupsi dapat mengambil bentuk menerima sogok, uang kopi, salam tempel, uang semir, uang pelancar, baik dalam bentuk uang tunai atau benda atau wanita, d) Umumnya serba rahasia, kecuali sudah membudaya, C) Melibatkan elemen kewajiban dan keuntungan timbal balik yang tidak selalu berupa uang, e) Setiap tindakan korupsi mengandung penipuan, biasanya pada badan publik atau masyarakat umum, f) Setiap perbuatan korupsi melanggar norma-norma tugas dan pertanggungjawaban dalam tatanan masyarakat g) Di bidang swasta korupsi dapat berbentuk menerima pembayaran uang, dan sebagainya, untuk membuka rahasia perusahaan tempat seseorang bekerja, mengambil komisi yang seharusnya hak perusahaan. ${ }^{14}$

\section{Upaya Pemerintah Daerah Dalam Meminimalisir Terjadinya Potensi Penyelewengan Alokasi Dana Desa.}

Kapasitas Aparatur Desa sebagai pelaksana kebijakan menjadi faktor penunjang keberhasilan pelaksanaan program-program yang dibiayai ADD. Kemampuan dan keterampilan Aparatur Desa sebagai pelaksana kebijakan

14 www.investigasi.or.id. Ciri-ciri korupsi (Tanggal 8 September 2015). 
merupakan dasar dari Pelaksanaan Pemerintahan khususnya di Bidang Keuangan dalam mengelola Alokasi Dana Desa. Kompetensi sumber daya manusia dalam diri pelaksana kebijakan ADD khususnya di bidang teknis yang kurang memadai berdasarkan tingkat pendidikan dan integritasnya. Kondisi ini berdampak pada kurangnya efektivitas pelaksanaan program akibat perlunya pembinaan terus menerus yang cukup menyita waktu yang dialokasikan.

Di sisi lain permasalahan yang muncul adalah kurang tepatnya pencapaian sasaran program. Artinya program-program yang semula dianggarkan untuk dibiayai seringkali digantikan oleh program lain yang ternyata memiliki kepentingan yang lebih besar untuk diprioritaskan. Kondisi ini menggambarkan adanya mekanisme penganggaran yang kurang matang sehingga terjadi kesalahan dalam penentuan prioritas pendanaan pada tahap awal. Indikasi awal yang menjadi dasar ketidaktepatan penentuan skala prioritas tersebut terletak pada kurangnya sosialisasi tentang kebijakan ADD sehingga kurang menyentuh pada masyarakat yang merupakan pelaksana langsung berbagai program yang didanai. Kurangnya sosialisasi berdampak pada kurangnya partisipasi masyarakat untuk memberikan usulan tentang program-program apa yang mendesak untuk dikedepankan guna didanai melalui ADD. Salah satu upaya meminimalisir terjadinya penyelewengan dalam ADD adalah dengan diterapkannya fungsi pengawasan pada setiap tahapan proses kegiatan

Pengawasan pelaksanaan alokasi dana desa tidak terlepas dari struktur tugas dan kewenangan serta pertangungjawaban sebagaimana disusun dalam struktur organisasi pelaksana. Struktur organisasi pelaksana alokasi dana desa Dibentuk dengan memberikan garis kewenangan dan tugas serta arah pertanggungjawaban antar fungsi yang jelas. Akan tetapi dalam pelaksanaannya di lapangan pelaksanaan fungsi belum sepenuhnya berjalan, terutama berkaitan dengan pelaksanaan fungsi yang melibatkan beberapa pejabat pelaksana serta LPMD yang diakibatkan Ketidak mengertian akan tugas dan tanggung jawab masing-masing sehingga mengurangi efektivitas pengawasan. Kurangnya koordinasi antar lini juga dirasa masih kurang 
sehingga beberapa fungsi terlihat bekerja secara terpisah dan menumbuhkan ketidakpercayaan.

Pengawasan juga tidak terlepas dari kapasitas sumber daya yang dimiliki. Sumber daya dalam implementasi suatu kebijakan merupakan salah satu faktor yang menjadi penentu. Pentingnya kesiapan agen pelaksana atau sumber daya dalam melaksanakan suatu kebijakan tidak bisa terlepas dari sumberdaya yang memadai bahwa para pelaksana harus disuplai dengan resources yang cukup, seperti human resources (staf dalam jumlah dan kualifikasi yang memadai dengan hak dan kewajibannya sesuai dengan kewenangan dan tanggung jawabnya), financial resources, technological resources, maupun psychological resources. ${ }^{15}$

Beberapa faktor pendorong penunjang keberhasilan program pemanfaatan alokasi dana desa antara lain :

1) Kemampuan pelaksana untuk memberi dorongan kepada masyarakat agar berpartisipasi dalam kegiatan ADD, meskipun hanya berupa tenaga dan material, 2) Adanya kemampuan pelaksana kebijakan ADD dalam melakukan identifikasi dan menyelesaikan masalah dalam pelaksanaan ADD, dan 3) Kelengkapan sarana/prasarana desa dalam mendukung kebijakan ADD.

Dari hasil pengamatan, baik secara administratif maupun pelaksana dilapangan, permasalahan umum yang dijumpai berkaitan dengan kegiatan pemanfaatan ADD di Kabupaten, antara lain, sosialisasi kebijakan ADD, kapasitas sumber daya manusia, dan peran serta masyarakat. Sementara itu masih terdapat kelemahan dalam hal sumber daya manusia dimana tingkat kemampuan pelaksana tidak merata, yaitu secara pendidikan masih rendah sehingga mempengaruhi kemampuan mengidentifikasi dan menyelesaikan masalah dengan cepat. Namun hal ini tidak mempengaruhi pelaksanaan ADD karena adanya kemampuan untuk menggerakkan masyarakat. Faktor penghambat dalam kaitannya dengan sumber daya manusia berpusat pada rendahnya pendidikan para pelaksana ADD, sehingga

15 M. Irfan Islamy, Prinsip-Prinsip Perumusan Kebijakan Negara. Bumi Aksara. Jakarta, 1998. HIm. 34. 
pemahaman pelaksana mengenai ADD kurang, serta tidak adanya dukungan yang memadai. Hal ini menimbulkan kurangnya dukungan pengawasan, terutama pengawasan oleh masyarakat sebagai penerima manfaat ADD.

Sebagaimana telah dibahas pada bagian sebelumnya peran serta masyarakat dinilai kurang memadai akibat kurangnya sosialisasi yang ditujukan bagi masyarakat. Hal ini menyebabkan masyarakat baik secara individu maupun melalui kelembagaan kurang memahami peran serta tugasnya. Dalam hal ini pemahaman masyarakat adalah membantu pelaksanaan secara fisik dari berbagai kegiatan implementasi ADD. Kondisi tersebut menyebabkan tidak ada peningkatan kapasitas masyarakat/lembaga masyarakat yang akhirnya menyebabkan rendahnya peran pengawasan oleh masyarakat.

Peningkatan kemampuan lembaga kemasyarakatan di desa dalam perencanaan, pelaksanaan dan pengendalian pembangunan tidak tercapai optimal, karena lembaga kemasyarakatan hanya dilibatkan dalam penyusunan rencana kegiatan dan pelaksanaan fisik. Sementara itu dalam pelaksanaan dan pengendalian dan proses administratif tidak dilibatkan. Terhadap kelamahan di atas, masyarakat berperan aktif dalam mengawasi kinerja aparat pemerintahan desa di Kabupaten. Disamping itu aparat pemerintah desa juga dituntut untuk transparan dalam berbagai bentuk kegiatan yang didanai oleh dana desa.

Hal ini, yang dimaksud dengan transparan adalah apabila semua elemen masyarakat dapat secara mudah mendapatkan segala informasi yang terkait dalam setiap proses kegiatan. Akuntabel dimaksudkan sebagai tanggungjawab dan tanggung gugat atas pelaksanaan setiap kebijakan dan keputusan yang telah dibuat kepada masyarakat maupun pihak lainnya, yang dimaksud partisipatif adalah, membuka ruang publik seluas-luasnya dalam perencanaan, pelaksanaan dan pengawasan seluruh proses kegiatan. Adapun yang dimaksud demokrasi adalah kebebasan seseorang untuk mengutarakan pendapat demi tujuan dan kemajuan bersama. Penyelewengan berbagai anggaran dalam program kegiatan desa, juga tidak terlepas dari kurangnya pembinaan yang diberikan oleh pemerintah kabupaten, maupun 
kecamatan. Oleh karena itu diperlukan pembinaan dan pengawasan dari kedua unsur pemerintahan tersebut.

Pembinaan dan pengawasan Pemerintah daerah Kabupaten di atur dalam Peraturan Pemerintah Nomor 72 Tahun 2005 Tentang Desa Pasal 101, antara lain:

1) Menetapkan pengaturan kewenangan kabupaten/kota yang diserahkan pengaturannya kepada desa; 2) Memberikan pedoman pelaksanaan tugas pembantuan dari kabupaten/kota ke desa; 3) Memberikan pedoman penyusunan peraturan desa dan peraturan kepala desa; 4) Memberikan pedoman teknis pelaksanaan dan pengembangan lembaga kemasyarakatan; 5) Memberikan pedoman penyusunan perencanaan pembangunan partisipatif; 6) Melakukan penelitian tentang penyelenggaraan pemerintahan desa; 7) Melakukan evaluasi dan pengawasan peraturan desa; 8) Menetapkan pembiayaan alokasi dana perimbangan untuk desa; 9) Mengawasi pengelolaan keuangan desa dan pendayagunaan aset desa; 10) Melakukan pembinaan dan pengawasan penyelenggaraan pemerintahan desa dan lembaga kemasyarakatan; 11) Memfasilitasi keberadaan kesatuan masyarakat hukum adat, nilai adat istiadat, lembaga adat beserta hak-hak tradisionalnya dalam pelaksanaan pemerintahan desa; 12) Menyelenggarakan pendidikan dan pelatihan bagi pemerintah desa dan lembaga kemasyarakatan; 13) Menetapkan pakaian dan atribut lainnya bagi kepala desa, perangkat desa dan BPD sesuai dengan kondisi dan sosial budaya masyarakat setempat; 14) Memberikan penghargaan atas prestasi yang dilaksanakan dalam penyelenggaraan pemerintahan desa dan lembaga kemasyarakatan; 15) Memberikan sanksi atas penyimpangan yang dilakukan oleh kepala desa sebagaimana diatur dalam peraturan perundangundangan; dan 16) Melakukan upaya-upaya percepatan atau akselerasi pembangunan perdesaan.

Sementara itu, dari pihak kecamatan, pembinaan dan pengawasan dilakukan

terhadap hal-hal yang di atur dalam Peraturan Pemerintah Nomor 72 Tahun 2005

Tentang Desa Pasal 102 sebagai berikut:

1) Memfasilitasi penyusunan peraturan desa dan peraturan kepala desa; 2) Memfasilitasi administrasi tata pemerintahan desa; 3) Memfasilitasi pengelolaan keuangan desa dan pendayagunaan aset desa; 4) Memfasilitasi pelaksanaan urusan otonomi daerah kabupaten/kota yang diserahkan kepada desa; 5) Memfasilitasi penerapan dan penegakan peraturan perundangundangan; 6) Memfasilitasi pelaksanaan tugas kepala desa dan perangkat desa; 7) Memfasilitasi upaya penyelenggaraan ketentraman dan ketertiban umum; 8) Memfasilitasi pelaksanaan tugas, fungsi, dan kewajiban lembaga kemasyarakatan; 9) Memfasilitasi penyusunan perencanaan pembangunan partisipatif; 10) Memfasilitasi kerjasama antar desa dan kerjasama desa 
dengan pihak ketiga; 11) Memfasilitasi pelaksanaan pemberdayaan masyarakat desa; 12) Memfasilitasi kerjasama antar lembaga kemasyarakatan dan kerjasama lembaga kemasyarakatan dengan pihak ketiga; 13) Memfasilitasi bantuan teknis dan pendampingan kepada lembaga kemasyarakatan; dan 14) Memfasilitasi koordinasi unit kerja pemerintahan dalam pengembangan lembaga kemasyarakatan.

Dari kedua pasal di atas jelas bahwa peran aktif dari Pemerintah Kabupaten dan Kecamatan dapat meminimalisir terjadinya penyelewengan terhadap berbagai kegiatan yang dibiayai oleh ADD. Hal ini tidaklah berlebihan mengingat berbagai tindak penyelewengan dana yang terjadi di Desa, baik dana yang berasal dari pemerintah (ADD) maupun dana dari sumber lainnya, semuanya terjadi karena lemahnya pengawasan, baik dari pemerintah yang lebih tinggi maupun dari masyarakat.

\section{PENUTUP.}

\section{A. Kesimpulan.}

1. Kebijakan pengelolaan Alokasi Dana Desa (ADD) di atur bahwa, Pengelolaan ADD sepenuhnya merupakan tanggung jawab Kepala Desa, yang dalam pelaksanaannya diserahkan kepada Petugas Teknis Pengelola Keuangan Desa (PTPKD) yang terdiri dari Sekretaris Desa dan Kepala Urusan Keuangan Desa; Penggunaan dana ADD adalah untuk belanja aparatur dan operasional Pemerintah Desa sebesar 30\% (tiga puluh persen) dari ADD yang diterima desa dan untuk biaya pemberdayaan masyarakat sebesar $70 \%$ (tujuh puluh persen) dari ADD yang diterima desa; Pertanggungjawaban ADD terintegrasi dengan pertanggungjawaban Anggaran Pendapatan Belanja Desa, sehingga bentuk pertanggungjawabannya adalah pertanggungjawaban APBDesa. Adapun peruntukannya adalah untuk menanggulangi dan mengurangki kemiskinan, meningkatkan pembangunan desa dan pemberdayaan masyarakat, meningkatkan pembangunan infrastruktur perdesaan, meningkatkan pengamalan nilai-nilai keagamaan, sosial budaya dalam rangka mewujudkan 
peningkatkan sosial; meningkatkan ketentraman dan ketertiban masyarakat, meningkatkan pelayanan kepada masyarakat desa dalam rangka pengembangan kegiatan sosial dan ekonomi masyarakat, mendorong peningkatkan keswadayaan dan gotong royong masyarakat dan meningkatkan pendapatan desa dan masyarakat desa melalui Badan Usaha Milik Desa.

2. Potensi penyelewengan ADD terjadi disebabkan oleh berbagai hal antara lain, menggunakan ADD untuk keperluan lain, mengalihkan dana untuk program lain, memasukan kegiatan baru yang sebelumnya tidak direncanakan, memanipulasi laporan ADD, menggunakan ADD untuk menutupi setoran PBB, pembelian untuk keperluan pribadi yang mengatasnamakan kebutuhan desa, pengalokasian ADD tidak sesuai dengan ketentuan, tidak melakukan kegiatan kemasyarakatan yang seharusnya dibiayai oleh ADD.

3. Upaya-upaya yang dapat dilakukan guna meminimalisir penyelewengan dana ADD antara lain: melakukan sosialisasi mengenai ADD, peningkatan peran serta masyarakat dan Sumber Daya Manusia (SDM) baik sebagai pelaku teknis maupun sebagai pihak yang melakukan pengawasan terhadap pengalokasian dana desa dari tahap awal sampai pelaporan.

\section{B. Saran.}

1. Hendaknya Kepala Desa beserta jajaran aparaturnya, dalam penggunaan ADD setiap tahunnya tidak hanya terfokus pada satu program yang menjadi prioritas yang sama pada tahun sebelumnya;

2. Jjadikan program-program lain sebagai prioritas, terutama kegiatan-kegiatan yang langsung menyentuh kebutuhan masyarakat.

3. Hendaknya fungsi pengawasan dari pihak yang lebih tinggi yang dalam hal ini pihak kecamatan dilaksanakan secara rutin pada setiap bentuk kegiatan yang didanai dari ADD, guna mengetahui kondisi objektif dilapangan. 


\section{DAFTAR PUSTAKA}

\section{A. Buku.}

Bayu Sukmawan Budiyono, Pelaksanaan Kebijakan Alokasi Dana Desa Berdasarkan Permendagri No. 37 Tahun 2007 Tentang Pedoman Pengelolaan Keuangan Desa, Jurnal ilmiah, Fakultas Hukum Universitas Brawijaya, Malang, 2013

Hamzah Halim dan Kemal Redindo Syahrul Putera, Cara Praktis Menyusun \& Merancang Peraturan Daerah; Suatu Kajian Teoritis \& Praktis Disertai Manual; Konsepsi Teoritis Menuju Artikulasi Empiris, Kencana Prenada Media Group, Jakarta, 2010.

Mardiasmo, Otonomi dan Manajemen Keuangan Daerah, penerbit ANDI, Yogyakarta, 2004.

Maryunani, Keuangan dan Ekonomi Desa, makalah Pada Universitas Brawijaya, Malang, 2006.

Maurice Duverger, dalam Kuntjoro Purbopranoto, Sistem Pemerintahan Demokrasi, cet 3. PT.Eresco, Bandung, 1978.

M. Irfan Islamy, Prinsip-Prinsip Perumusan Kebijakan Negara. Bumi Aksara. Jakarta, 1998

\section{B. Perundang-Undangan.}

Undang-Undang Dasar 1945.

Undang-Undang Nomor 17 Tahun 2003 Tentang Keuangan Negara;

Undang-Undang Nomor 1 Tahun 2004 Tentang Perbendaharaan Negara;

Undang-Undang Nomor 10 Tahun 2004 Tentang Pembentukan Peraturan PerundangUndangan;

Undang-Undang Nomor 32 Tahun 2004 Tentang Pemerintahan Daerah Sebagaimana Telah Diubah Keduakalinya Dengan Undang-Undang Nomor 12 Tahun 2008;

Peraturan Menteri Dalam Negeri Nomor 37 Tahun 2007 tentang Pedoman Pengelolaan Keuangan Daerah.

Peraturan Menteri Dalam Negeri Nomor 4 Tahun 2007 Tentang Pengelolaan Kekayaan Desa 


\section{Jurnal.}

Menjembatani Penelitian dan Kebijakan, dikutip dari http://www.smeru.or.id, 7 September 2015.

Sukesi, Efektivitas Program Alokasi Dana Desa (ADD) Terhadap Perekonomian Desa Di Kabupaten Pacitan, Jurnal Ilmiah, Universitas Dokter Sutomo, Surabaya, Vol. 1 Desember Tahun 2007

www.investigasi.or.id. Ciri-ciri korupsi (Tanggal 8 September 2015). 